Article

\title{
Fishers' Perceptions and Attitudes toward Weather and Climate Information Services for Climate Change Adaptation in Senegal
}

\author{
Ndèye Seynabou Diouf ${ }^{1, *}$, Issa Ouedraogo ${ }^{1}$ (D) Robert B. Zougmoré ${ }^{1}$ and Madické Niang ${ }^{2}$ \\ 1 CGIAR Research Program on Climate Change, Agriculture and Food Security (CCAFS), ICRISAT West \\ \& Central Africa Regional Office, Bamako BP 320, Mali; i.ouedraogo@cgiar.org (I.O.); \\ r.zougmore@cgiar.org (R.B.Z.) \\ 2 Initiative Prospective agricole et rurale (IPAR), Kër Jacques Faye, Ouest Foire-Dakar BP 16788, Senegal; \\ madickee@yahoo.fr \\ * Correspondence: S.Diouf@cgiar.org; Tel.: +223-7753-20427
}

Received: 19 August 2020; Accepted: 2 November 2020; Published: 13 November 2020

\begin{abstract}
Climate variability has become a major issue for vital sectors in the context of climate change. In fisheries, in particular, the effects of climate change are reflected in the decline of fishing yield and loss of lives during extreme weather events in the sea. This study analyzed the perception of climate variability and change by fisher-folks, the attitude of fisher-folks toward the weather forecast and the adoption rate of the use of the weather forecast as well as the factors determining its use in Senegal. To this end, 576 fisher-folks belonging to 41 local fishing committees along the coastal areas were surveyed and focus group discussions were organized with key informants. The adoption rate was identified using the method of the average treatment effect (ATE) and the test of independency (chi-square) was used to analyze the perceptions of and beliefs on climate change. The results showed that $96 \%$ of fisher-folks perceive the change in the climate, though the effects are differently appreciated across the coastline. The most frequently observed effects are: coastal erosion, change in wind direction, increase in extreme swells and sea level rise. Nearly half of fisher-folks confirm that they noticed these changes over the past five years. In the Southern Coast in particular, $40 \%$ of fisher-folks stated that these changes happened 10 years ago. This statement is confirmed by the qualitative data. More than $90 \%$ of the respondents ascertain the weather forecast before going to fish, $63 \%$ regularly receive the weather forecast and $53 \%$ avoid going to sea during extreme events. In addition, the results showed that if the weather forecast was made accessible to the majority of fisher-folks, more than $83 \%$ would avoid going to sea during periods of extreme weather extreme events, thus reducing significantly the number of fatalities. The best way to protect the fisher-folks from the harmful effects of climate change is to ensure large-scale access to and use of accurate weather forecasts.
\end{abstract}

Keywords: climate; weather and climate information services; fisher folks; perceptions

\section{Introduction}

Climate change (CC) is a global phenomenon that affects all sectors of human activities. According to Adger et al. [1], risks are apparent in agriculture, fisheries and many other sectors that constitute the basis of the livelihood of rural populations in developing countries. Also, Ninawe et al. [2] argued that oceans and seas are the most affected by the process of change caused by global warming as they represent a large portion of our planet and have rich biodiversity. Indeed, a temperature increase of only a few degrees gives rise to hydrological events that cause change in the physical and chemical characteristics of water. Climate change has both direct and indirect impacts on fish stocks that are 
exploited commercially [3] and may lead to substantial reduction in marine fish production and decline in fish protein supply in the West Africa region by the 2050s [4]. This contributes to a decline in fisheries-related jobs and a total annual loss of $\$ 311$ million in the whole economy of West Africa [5]. These changes are expected to increase the vulnerability of the regions' economy and food systems to climate change [5]. A report from Intergovernmental Panel on Climate Change (IPCC) on the potential vulnerabilities of the national economies to the effects of climate change in the fishing sector concluded that a number countries including Senegal are the most vulnerable [6].

In Senegal, the fisheries sector employs 600,000 persons and contributes to the national economy (12\% of the GDP) and to people's diets (72\% of animal protein and $47 \%$ of the total protein in the national diet) [7]. The artisanal fisheries are involved in the most important activities in the sector in terms of volumes caught $(80 \%)$ and number of active fisher-folks [8]. Artisanal fisheries are made up of fishers who use traditional canoes and non-mechanized gears for fishing in the sea. The fishers use ice and salt to cool and conserve the catches [9]. The coastal zones of Senegal are also affected by an intensification of extreme weather events, namely, swell events, sea level and temperature rise, and changes in upwelling phenomenon [6]. This, among other factors, has led to the increase in coastal erosion, the salinization of water and soil, the modification of the structure and composition of marine species and, more prominently, the increase of fatalities in the sea. In 2017, 140 fatalities due to extreme weather events in the sea were reported and the loss of fishing materials amounted to 250,000 \$US. In order to improve the resilience of the fishing communities and their safety in the sea, the Senegalese authorities in collaboration with the United State Agency for International Development (USAID) initiated an early warning system on extreme weather events in 2014. This initiative, implemented by the national meteorological office (ANACIM), aimed at providing the fishing communities with salient weather and climate information services (WCIS) that are essential for informed and conscious decision-making [10]. The weather forecast communicate to the fishing communities through SMS and voice messages are but not limited to extreme tide, swell, visibility and wind events. Aggarwal et al. [10] reported that the weather forecasts are vital for fisher-folks. However, the use of weather forecast as an adaptation practice cannot be effective if the users are not aware of the existence of climate change and its related risks. In fact, the use of weather forecast as an adaptation strategy integrates at least the following issues cited by Sall et al. [11]: the awareness of climate change and its impacts on production systems, and the perception of the extent of its effects. While numerous studies have examined the impact of and adaptation to climate change on fisheries $[1,2,5,12,13]$, so far only few studies $[6,14-16]$ have explored fisher-folks' perceptions of climate change. Moreover, studies on the adoption rate of weather forecasting in fisheries in Senegal are non-existent. In this paper, we analyzed fisher-folks' perception of climate change and their attitudes toward weather forecast along the coast of Senegal. We hypothesized that the fisher-folks are aware of the climate-related risks and are willing to act to adapt to the effects of climate change. Therefore, this study aimed specifically to determine (i) the perception of climate variability and change as perceived by fisher-folks; (ii) the attitudes of fisher-folks toward weather forecast, and (iii) the adoption rate of the use of weather forecast and factors that determine its use. The study is a contribution to the better understanding of the usefulness of the weather forecast for fisher-folks in West African coastal countries.

\section{Materials and Methods}

\subsection{Study Sites Characteristics}

This study was conducted along the coastal areas of Senegal that gathers the majority of the fishing communities (Figure 1). The coastline is divided into three eco-geographic sites as follow:

- The "Great Coast" extends from the estuary of the Senegal River to the peninsula of Cape Verde. It concentrates the largest fishing centers such as Saint Louis, Fass Boy and Kayar. This area is subjected to climatic hazards such as floods, coastal erosion and drought [17]. In 2003, the government decided to dig a breach to relieve the population from recurrent flooding. 
This has increased the coastal erosion making the community even more vulnerable to extreme weather events.

- The "Small Coast" is located between the Bay of Hann and Djiffer. It is bounded on the north by the peninsula of Cape Verde, to the west by the Atlantic Ocean, to the South by latitude $14^{\circ} 54^{\prime}$ North. This area is experiencing erosion, water salinization and degradation of the mangroves [13]. It has been estimated that $37 \%$ of mangrove areas will be lost in the event of a sea level rise of $0.5 \mathrm{~m}$ by 2100 [18]. This area is also highly exposed to the extreme weather forecast.

- Finally, the Southern Coast (Casamance) extends from The Gambia to Guinee Bissau comprises the Saloum River through the estuary zones.

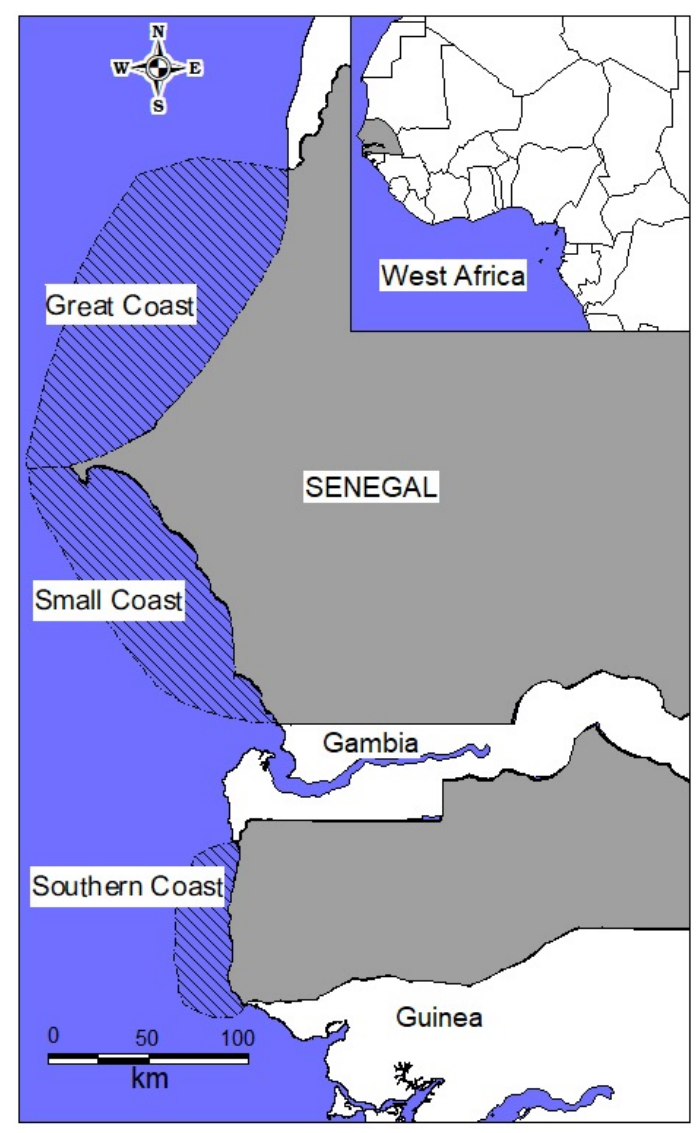

Figure 1. Sites study.

\subsection{Data Collection}

The study was carried out in 2017 and used an empirical approach that includes focus group discussion and surveys to collect the data. Three focus group discussions were organized in each coastal zone (Great Coast, Small Coast and Southern Coast) with 6-12 participants depending on the availability of participants. Data collected was related to the access, the use and the understanding of weather information, the traditional climate forecasts and the perceptions on climate change. A questionnaire was used to collect quantitative information on the socio-economic characteristics of respondents, management of the fishing activity, perceptions of climate change, attitude toward weather forecast, access to and use of weather forecast. The respondents are fisher-folks who live along the coastal areas and who belong to the Local Artisanal Fishing Committee (CLPA). The role of the CLPA is to validate and ensure the co-management measures and rules taken by the actors in terms of sustainable management of fishery resources. Forty-one (41) CLPAs were established along the coastal area. We used the data base of the members of each CLPA to randomly select the respondents. For each CLPA, $9 \%$ of members were randomly surveyed, totaling 576 fisher-folks along the coastal 
area. Nearly no women are represented in the fishing activities. They are involved, in particular, in the processing, storage and distribution of fresh fish.

\subsection{Data Analysis}

Data from the focus group discussion was used to support the results from the analysis of quantitative data. Depending on the type of analysis, several tests were performed as described below.

\subsubsection{Fishers' Perceptions of Climate Change}

The perceptions were analyzed through the awareness of individuals regarding climate change and its manifestations. Information related to the perceptions of climate change for fisher-folks in the different geographic areas were analyzed using the test of independency (chi-square) to assess whether there is an association between the variables and the geographical categories. The variables are the types of changes observed (e.g., wind direction, extreme swells events, increased tides, coastal erosion, etc.), the starting date of perceived changes (past five years, past ten years, past fifteen years, etc.). In addition, some statements were also given to respondents to identify the attitude toward weather forecast.

Chi-square test is a nonparametric test used for two specific purposes: (a) to test the hypothesis of no association between two or more groups, population or criteria (i.e., to check independence between two variables), and (b) to test how likely the observed distribution of data fits with the distribution that is expected (i.e., to test the goodness-of-fit) [19]. More specifically, this statistic is used to determine whether there is any difference between the study groups in the proportions of the risk factor of interest. Chi-square test and the logic of hypothesis testing were developed by Karl Pearson. The formula for calculating chi-square is the following [20]:

$$
x^{2}=\sum_{i=1}^{n} \frac{\left(O_{I}-E_{i}\right)}{E_{i}}
$$

where $O$ stands for the observed frequency and $E$ the expected frequency

\subsubsection{Parametric Estimation of the Weather Forecast Adoption Rate}

The adoption rate was identified using the method of the Average treatment Effect (ATE) estimation proposed by Diagne and Demont [21]. The ATE parameter measures the effect or impact of a "treatment" on a person randomly selected in the population [22]. The treatment corresponds to exposure to the weather forecast. The ATE is the population mean adoption outcome when all members of the population have been exposed to a technology and it is, therefore, a measure of the intrinsic value of the technology as indicated by its potential demand by the population. The difference between the population mean potential adoption outcome and the population actual (observed) adoption outcome is the non-exposure bias, also known as adoption gap, which exists because of incomplete diffusion of the technology in the population [23]. The gap is the difference between the actual adoption rate and the potential adoption rate. It gives the percentage of people who may use the weather forecast if they get access to the weather forecast. There is another parameter of interest, which is average treatment effect on the treated, commonly denoted as ATE1 or ATT [22]. ATE1 is the mean adoption outcome within the sub-population of exposed fisher-folks. The difference between the population mean adoption outcome (ATE) and the mean adoption outcome among the exposed (ATE1) is the population selection bias, PSB (for details, see [21,24]). The exposition on this study refers both to (i) the access to weather forecast related to the marine weather and (ii) the understanding of the weather forecast and associate decisions. The information and communication technology such as SMS or voice call has been used for the dissemination of the weather forecast to fisher-folks. The adoption or use of weather forecast in this study refers to the decision of avoiding the sea during the phenomenon on extreme swell events. 
The parametric estimation of ATE is executed by first specifying a parametric model. The method used only the sub population of exposed fisher-folks to identify ATE. We used the following equation for the identification:

$$
E(y \mid x, w)=1=g(x, \beta)
$$

where $g$ is function of the vector of covariates $x$ and the unknown parameter vector $\beta$ which is to be estimated using standard least squares (LS) using the observations $\left(y_{i} x_{i}\right)$ from the sub sample of exposed fisher-folks only; $y$ is a dependent variable and $x$ the vector of explanatory variables. With an estimated parameter $\beta$, the predicted values $g\left(x_{i}, \beta\right)$ are computed for all observations (exposed and non-exposed sub sample) and the parameters ATE, ATE1 and ATE0 are estimated by taking the average of the predicted $g\left(x_{i}, \beta\right) \mathrm{i}=1, n$ across the full sample:

$$
\begin{gathered}
A \hat{T} E=\frac{1}{n} \sum_{i=1}^{n} g\left(x_{i}, \hat{\beta}\right) \\
A \hat{T} E 1=\frac{1}{n_{e}} \sum_{i=1}^{n_{e}} w_{i} g\left(x_{i}, \hat{\beta}\right) \\
A \hat{T} E 0=\frac{1}{1-n_{e}} \sum_{i=1}^{n}\left(1-w_{i}\right) g\left(x_{i}, \hat{\beta}\right)
\end{gathered}
$$

All the estimations were done in Stata using the Stata add-on adoption command developed by Diagne and Demont [21].

\subsubsection{Determinants of the Use of Weather Forecast}

Two probit regression was carried out to identify the socioeconomic variables that influence the adoption of weather forecast. One was performed using the full sample while the second use the sub sample constituted by the those who get access to weather forecast. Probit models use the cumulative Gaussian normal distribution for calculating the probability of being in one category or not [25]. The use of weather forecast was the dependent variable and the independent variables are the following: ethnicity, write and read French, canoe owner, part of a fisher-folk association, training on climate change, receive weather forecast through SMS, receive weather forecast through CLPA, total income, age, never been in school, perceive change in climate change, Small Coast, Great Coast. These variables are presented in Tables 1 and 2.

Table 1. Socio-economic characteristics of respondents.

\begin{tabular}{ccc}
\hline Observations & $n$ & \% \\
\hline Geographical Area & & \\
\hline Great Coast & 296 & 51.39 \\
Small Coast & 150 & 26 \\
Southern Coast (Casamance) & 130 & 22.57 \\
\hline Household (HH) Characteristics & \\
\hline HH head & 376 & 65.28 \\
Ethnicity (Wolof) & 263 & 45.66 \\
Ethnicity (Serere) & 114 & 19.79 \\
Ethnicity (Lebou) & 66 & 11.46 \\
Married & 494 & 85.76 \\
Single & 73 & 12.67 \\
Literate in local language & 361 & 62.67 \\
\hline
\end{tabular}


Table 1. Cont.

\begin{tabular}{ccc}
\hline Observations & $n$ & $\%$ \\
\hline Literate in French & 263 & 45.66 \\
Native & 475 & 82.46 \\
Migrant & 101 & 17.53 \\
Member of fisher-folks' association & 205 & 70.45 \\
\hline Age Class of Respondents & & \\
\hline Less than 30 & 75 & 13.02 \\
Between 30 to 50 & 335 & 58.16 \\
Between 50 to 60 & 119 & 20.66 \\
More than 60 & 47 & 8.16 \\
\hline Characteristics of Fishing Activities & \\
\hline Fishing as main activity & 565 & 98 \\
Fish trader & 9 & 1.56 \\
Crew member & 131 & 22.74 \\
Canoe owner & 322 & 55.90 \\
Captain & 442 & 76.73 \\
Fishing technique: Hook and line technology & 246 & 11.11 \\
Fishing technique: Passive gear & 64 & 6.59 \\
Trained in climate change & 38 & 14.06 \\
Access to weather forecast via radio & 81 & 10.24 \\
Access to weather forecast via SMS & 59 & 18.58 \\
\hline
\end{tabular}

Table 2. Age and household size.

\begin{tabular}{ccccccc}
\hline Observations & $n$ & Mean & Std Dev & Min & Max & Median \\
\hline \multicolumn{2}{c}{ Age and Household Size } & & & & & \\
\hline Average age & 576 & 42 & 11.5 & 15 & 79 & 41 \\
Household size & 576 & 14 & 7.9 & 1 & 80 & 12 \\
\hline
\end{tabular}

\section{Results}

\subsection{Socio Economics Characteristics of Respondents}

Tables 1 and 2 present the characteristics of 576 respondents. About $51 \%$ of respondents reside in the Great Coast, 26\% in the Small Coast and 22\% in the Southern Coast. More than 65\% are household heads and the average age is 42 years. The most represented ethnic groups are "Wolof" (46\%) and "Serere" (20\%). About 86\% of the respondents are married and the average size of the households is 14 . About $46 \%$ can write and read in the French language. For $98 \%$ of the respondents, fishing remains the main activity and $15 \%$ are doing fish trading as second activity. More than $79 \%$ plays the role of captain. About $18 \%$ of the respondents get access to weather forecast through the fishing community association (CLPA). Few people (less than 7\%) were trained in climate change through partnerships with technical and financial partners such as USAID and the National Fisheries Office.

\subsection{Access to and Level of Knowledge of the Weather Forecast}

Table 3 presents the level of access to weather information. We notice that $60 \%$ of fisher-folks in the Great Coast get access to weather forecast, whereas 53\% in the Southern Coast and $77 \%$ in the Small Coast get access. On average, $63 \%$ of respondents in the full sample get regularly access to weather forecast. 
Table 3. Level of access to weather forecast.

\begin{tabular}{ccccccccc}
\hline \multirow{2}{*}{ Level of Access } & \multicolumn{2}{c}{ Great Coast } & \multicolumn{2}{c}{ Small Coast } & \multicolumn{2}{c}{ Southern Coast } & \multicolumn{2}{c}{ Total } \\
\cline { 2 - 9 } & $n$ & $\%$ & $n$ & $\%$ & $n$ & $\%$ & $n$ & $\%$ \\
\hline Access & 179 & $60 \%$ & 115 & $77 \%$ & 69 & $53 \%$ & 363 & $63 \%$ \\
\hline No Access & 117 & $40 \%$ & 35 & $23 \%$ & 61 & $47 \%$ & 213 & $37 \%$ \\
\hline \multicolumn{4}{c}{ Pearson chi2 $(2)=18.3258, \operatorname{Pr}=0.000}$.
\end{tabular}

Figure 2 presents the level of awareness of relevant weather information in the fishing sector. It appears that fisher-folks in the Great Coast are aware of the different type of forecasts, while in the Southern Coast, the level of awareness is lower; the difference observed between the area is statically significant.

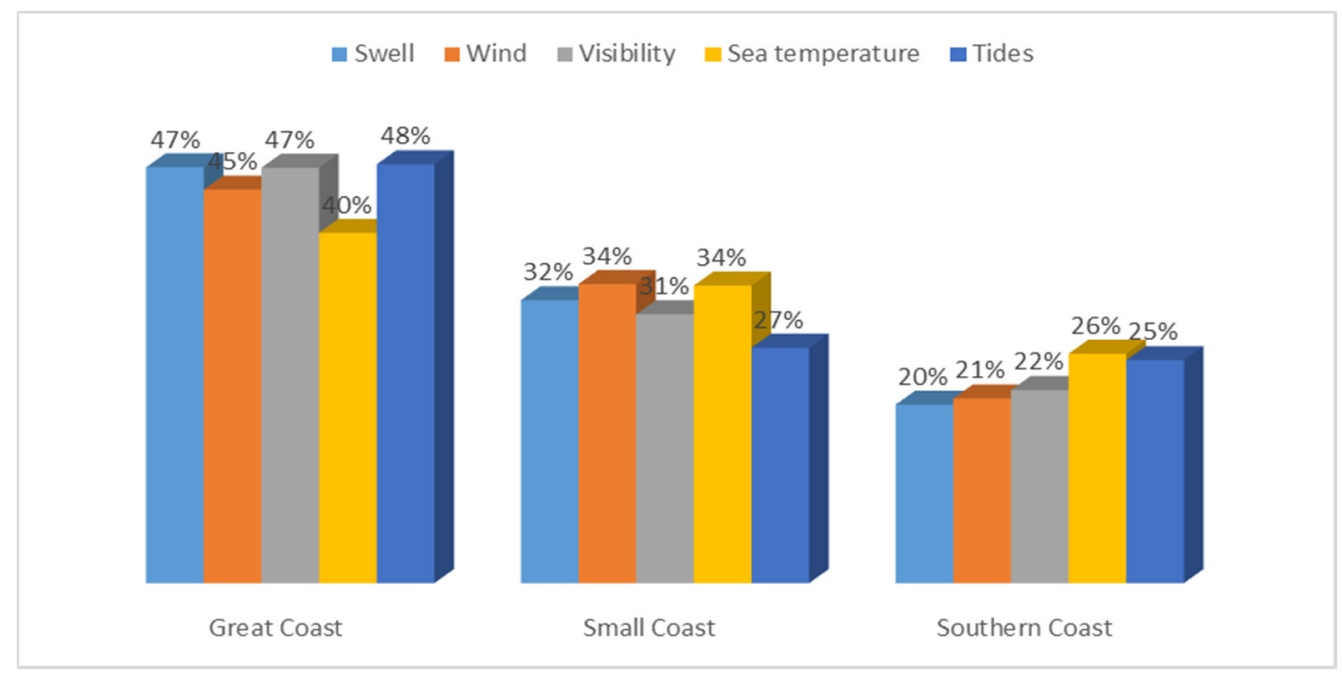

Figure 2. Level of knowledge on weather forecast.

\subsection{Perception of Climate Change}

Findings (Figure 3) indicate that $96 \%$ of fisher-folks perceive the change in the climate. Fisher-folk's perceptions of climate change are based on climate related manifestations. Depending on the area, fisher-folks differentiate the effects of climate change. In the Great Coast, people perceive climate change through coastal erosion (37\% of respondents), wind direction (32\%) and increased extreme swell events (31\%). Some people said that the coastal erosion (26\%) and the accidents in the sea $(20 \%)$ have occurred regularly during these last years. In the Small Coast, wind direction, increased extreme swell events, coastal erosion and sea level rise were mentioned. In the Southern Coast, respondents have pointed firstly the decreased fish population (21\%), the disappearance of species $(20 \%)$ and the change in wind direction (16\%). In addition, $13 \%$ have enumerated the increased tides and $9 \%$ the increased extreme swell events.

Regarding the estimated date they perceive these changes (Table 4), nearly half of fisher-folks confirm that they noticed changes over the past five years. About $25 \%$ of fisher-folks perceived these changes over the last 10 years, for $13 \%$ these changes had started 15 years ago, while $7 \%$ overall think these changes have occurred since 20 years ago. The trends on the onset of these changes are practically the same from one zone to another, except the southern Coast, where we note the greatest percentage of fisher-folks who stated these changes have happened since 10 years ago. 


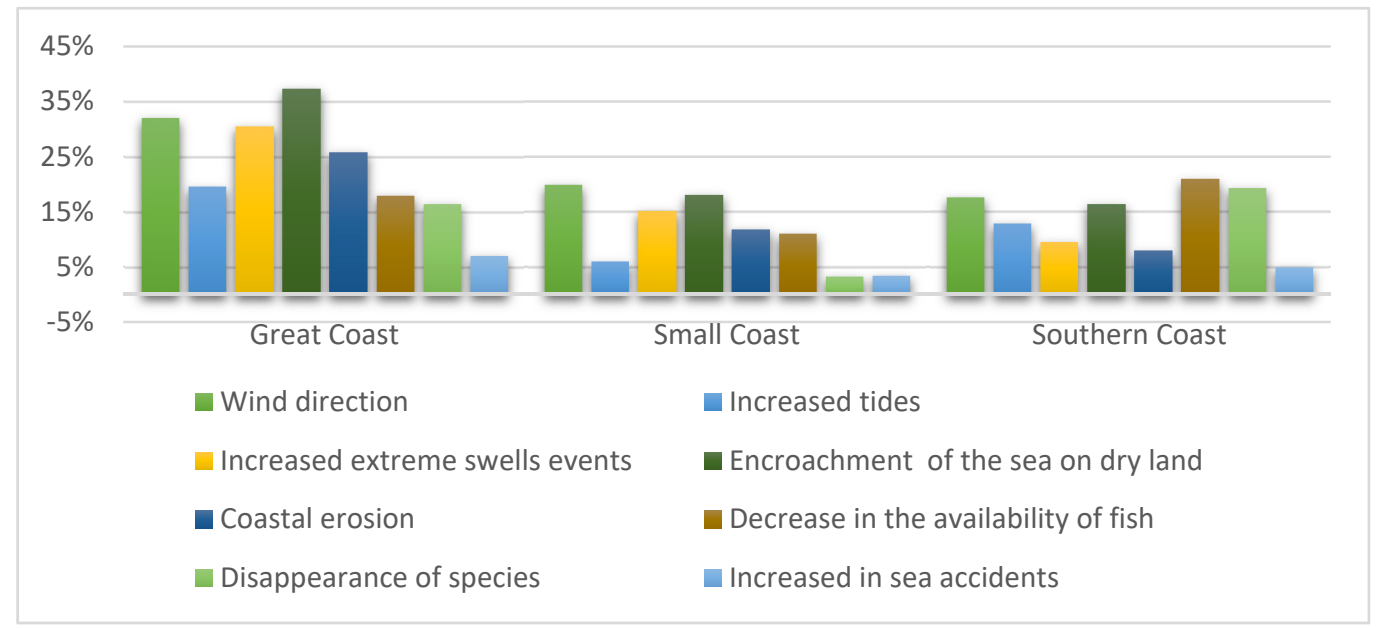

Figure 3. Perceptions of climate change by fisher-folk.

Table 4. Start date of perceived changes.

\begin{tabular}{|c|c|c|c|c|c|c|c|c|}
\hline \multirow{2}{*}{$\begin{array}{l}\text { When Did You Perceive This } \\
\text { Change in The Climate }\end{array}$} & \multicolumn{2}{|c|}{ Great Coast } & \multicolumn{2}{|c|}{ Small Coast } & \multicolumn{2}{|c|}{ Southern Coast } & \multicolumn{2}{|c|}{ Total } \\
\hline & $n$ & $\%$ & $n$ & $\%$ & $n$ & $\%$ & $n$ & $\%$ \\
\hline Past five years & 147 & $53 \%$ & 78 & $55 \%$ & 36 & $29 \%$ & 261 & $48 \%$ \\
\hline Past ten years & 49 & $18 \%$ & 40 & $28 \%$ & 50 & $40 \%$ & 139 & $26 \%$ \\
\hline Past fifteen years & 30 & $11 \%$ & 15 & $11 \%$ & 28 & $22 \%$ & 73 & $13 \%$ \\
\hline Past twenty years & 22 & $8 \%$ & 9 & $6 \%$ & 11 & $9 \%$ & 42 & $8 \%$ \\
\hline Others & 28 & $10 \%$ & 1 & $1 \%$ & 1 & $1 \%$ & 30 & $6 \%$ \\
\hline Total & 276 & & 143 & & 126 & & 545 & \\
\hline
\end{tabular}

Data from the focus group discussion confirm these results. Indeed, respondents explained the changes they have noticed on the climate during the last years and their consequences. The most notable changes are, among others, the coastal erosion and the sea level rise. The decreased rainfall is also cited by the respondents. For them, the rains were more abundant in the 1950s, while in recent years the onset of the season occurs in July with low intensity. This phenomenon amplifies and prolongs the effects of the rise in the level of salinity, which has repercussions on the quantity of fishery resources as well as on their quality.

Participants in the focus group discussions mentioned that the various changes have direct effects on household food security. Indeed, the scarcity of fishery resources in areas like Ziguinchor (Southern Coast) makes it more difficult to supply fish compared to meat. Although fishing factories in this area create jobs for young people, the scarcity of fishery resources entails risks of their activities to decline or even their closure. In Saint Louis (Great Coast), the fish processing activity is strongly threatened by the decrease in the quantities of fish. Fishing stakeholders in these different areas have pointed out a sharp increase in temperature with a high variability over time.

They also argued that these various changes make difficult to plan their fishing activities: "in the end, we no longer know what to expect". A fisherman from the Great Coast (Saint Louis) noted that, in November in general, the cold weather favors the abundance of fish. However, with in increasing temperatures, there is no longer a cold period, thus causing a decrease in the fish population. In addition, according to participants, in the Southern Coast as well as in the Small Coast (Foundiougne district) where the inland fishing is practiced, the mangroves are also largely affected by the effects of climate change and are, as such, threatened with disappearance. One of the participants mentioned that "previously, it was possible to take landmarks with mangroves to navigate and orient themselves in the sea, but the loss of a large part of this resource entails the risk of being lost for fisher-folks". 


\subsection{Attitude toward Weather Forecast}

Results show that people are aware of their responsibility to deal with the effect of climate change, wherever they are from (Table 5). They are willing to act toward resilient practices. More than $90 \%$ of the respondents enquire about the weather forecast before going to fish. This is confirmed by the participants of the focus group discussions. In addition, several people have decided to postpone their fishing activities during extreme meteorological phenomena. Results from chi-square disclosed that there is a large difference in the appreciation of the different statements across areas. In particular, wearing the life jacket is still unappreciated, in particular, in the Southern Coast, where only $57 \%$ of respondents consider it as required. In the Small Coast, about $13 \%$ of the respondents prevent their parent from going to the sea when extreme wind events are forecasted. In the Great and Sothern Coasts, however, $20 \%$ and $19 \%$ would strongly advise their parent against fishing in the sea in case of prominent occurrence of extreme events.

Table 5. Willingness to take decisions toward resilience practices.

\begin{tabular}{|c|c|c|c|c|c|}
\hline \multirow[b]{2}{*}{ Statements } & \multicolumn{3}{|c|}{ Area } & \multirow[b]{2}{*}{ Mean } & \multirow[b]{2}{*}{$p$ Value } \\
\hline & $\begin{array}{l}\text { Great } \\
\text { Coast }\end{array}$ & $\begin{array}{l}\text { Small } \\
\text { Coast }\end{array}$ & $\begin{array}{l}\text { Southern } \\
\text { Coast }\end{array}$ & & \\
\hline \multicolumn{6}{|l|}{$\begin{array}{l}\text { What do you think about the } \\
\text { following statements? }\end{array}$} \\
\hline & Yes & Yes & Yes & & \\
\hline $\begin{array}{c}\text { We should consult the Met services } \\
\text { before going to the sea }\end{array}$ & $98 \%$ & $98.6 \%$ & $92 \%$ & $96.2 \%$ & 0.006 \\
\hline $\begin{array}{l}\text { I will decide to turn back once at sea if } \\
\text { I learn the existence of an extreme } \\
\text { weather phenomenon the next day }\end{array}$ & $90 \%$ & $93 \%$ & $98 \%$ & $93.67 \%$ & 0.022 \\
\hline $\begin{array}{c}\text { I will decide to convince a sibling not } \\
\text { to go to sea due to the existence of an } \\
\text { extreme wind events }\end{array}$ & $78 \%$ & $85 \%$ & $78 \%$ & $80.3 \%$ & 0.16 \\
\hline $\begin{array}{l}\text { I decide to prohibit a parent from not } \\
\text { going to sea due to the existence of an } \\
\text { extreme wind event }\end{array}$ & $20 \%$ & $13 \%$ & $18.5 \%$ & $18.06 \%$ & 0.19 \\
\hline $\begin{array}{c}\text { Wearing the life jacket is necessary } \\
\text { regardless the weather }\end{array}$ & $71 \%$ & $87 \%$ & $57 \%$ & $71.67 \%$ & 0.00 \\
\hline
\end{tabular}

\subsection{Adoption Rate of the Use of Weather Forecast}

Table 6 presents the results of the adoption rate of weather forecast. The actual adoption rate of the use of weather forecast is $53 \%$. Results show also that the potential adoption rate would be about $83 \%$ in a case where the full sample have access to information related to extreme swell events. Additionally, results display that $63 \%$ of respondents have access to the weather forecast $(\mathrm{Ne} / \mathrm{N})$ and $53 \%(\mathrm{Na} / \mathrm{N})$ of fisher-folks avoid going to the sea for fishing activities during days with extreme swell events. Among those who got access or were exposed to weather forecasts, $84 \%$ have taken the decision to avoid the sea. This has been given by the ATE1 parameter, which is the adoption rate among those who have access to the weather forecast. This demonstrates that the process of behavioral change has started and fisher-folks are more aware of the danger of such events. Interviews from focus groups discussion have shown that there is a large number of fisher-folks who have lost at least one family member or their material during high swells. In addition, the difference between the observed and the potential adoption rates implies an adoption gap of $30 \%$. This result highlights the fact that there is a possibility to have $30 \%$ more people who avoid the sea during extreme swell events when the level of access increases. 
Table 6. ATE parametric (Probit) estimation of population adoption incidence rates (2017).

\begin{tabular}{|c|c|c|c|}
\hline & Parameter & Std. Err. & $P>\mathrm{z}$ \\
\hline ATE (Potential adoption rate) & 0.825 & 0.021 & 0 \\
\hline ATE1 (Adoption rate among exposed) & 0.840 & 0.018 & 0 \\
\hline ATE0 (Adoption rate among non-exposed) & 0.797 & 0.028 & 0 \\
\hline JEA (Joint Exposure and adoption rate) & 0.529 & 0.012 & 0 \\
\hline Population adoption gap (JEA-ATE) & -0.295 & 0.010 & 0 \\
\hline PSB (Population Selection Bias) & 0.0159 & 0.006 & 0.16 \\
\hline \multicolumn{4}{|c|}{$\begin{array}{l}\text { Number of exposed: } \mathrm{Ne}=363 \\
\text { Number of adopters: } \mathrm{Na}=305 \\
\text { Number of observations: } \mathrm{N}=576\end{array}$} \\
\hline \multicolumn{4}{|l|}{ Observed } \\
\hline $\mathrm{Ne} / \mathrm{N}$ & 0.63 & 0.02 & 0 \\
\hline $\mathrm{Na} / \mathrm{N}$ & 0.53 & 0.021 & 0 \\
\hline $\mathrm{Na} / \mathrm{Ne}$ & 0.84 & 0.033 & 0 \\
\hline
\end{tabular}

Results were analyzed based on the geographic location (Table 7). In the Great Coast, $65 \%$ of respondents have taken decision to postpone their fishing activities during extreme swell events, against $50 \%$ in the Small Coast and the same in the Southern Coast. Besides the recurrent phenomenon of extreme swell events in the high seas, it is observed that an important portion of fisher-folks have taken the risk to go to the sea. In addition, the focus group discussion showed that there are sociological considerations such as belief in the Protection of genius of the sea that influences fisher-folks to not pay attention to weather information.

Table 7. Use of weather forecast according to the area (2017).

\begin{tabular}{ccccccc}
\hline \multirow{2}{*}{ Use of Weather Forecast } & \multicolumn{2}{c}{ Great Coast } & \multicolumn{2}{c}{ Small Coast } & \multicolumn{2}{c}{ Southern Coast } \\
\cline { 2 - 6 } & Parameter & Std. Err. & Parameter & Std. Err. & Parameter & Std. Err. \\
\hline $\mathrm{Ne} / \mathrm{N}$ & 0.60 & 0.028 & 0.77 & 0.03 & 0.605 & 0.028 \\
$\mathrm{Na} / \mathrm{N}$ & 0.50 & 0.029 & 0.65 & 0.04 & 0.500 & 0.029 \\
$\mathrm{Na} / \mathrm{Ne}$ & 0.83 & 0.048 & 0.85 & 0.05 & 0.827 & 0.048 \\
\hline & $\mathrm{Nb}$ & $\mathrm{Nb}$. Obsposed $(\mathrm{N})=296$ & $\mathrm{Nb})=179$ & $\mathrm{Nb}$. Obs $(\mathrm{N})=150$ & $\mathrm{Nb}$. Obs $(\mathrm{N})=130$ \\
& $\mathrm{Nb}$. Adopters $(\mathrm{Na})=148$ & $\mathrm{Nb}$. Adopters $(\mathrm{Na})=115$ & $\mathrm{Nb})=98$ & $\mathrm{Nb}$. Adopters $(\mathrm{Na})=59$ \\
\hline
\end{tabular}

\subsection{Determinants of the Adoption of Weather Forecast}

Results in Table 8 show the determinants of the adoption of weather forecast. The classic model illustrates the factors that influence the use of the weather forecast in the full sample, whereas the parametric model focuses on the exposed sub population. Results from the classic model present that the ability to write and read in French as well as the possession of a mobile phone or a radio is essential for the access to and better use of weather information. People who are receiving the weather forecast via SMS or through the fishing association have a high probability to use the information adequately. Results depict also that the more the fisher-folks get older (involving being married and having children), the higher the probability to use the weather forecast. On the other hand, the ethnic group in particular "Serere" negatively affect the suitable use of the information. Finally, being from the Small Coast leads to the appropriate use of weather forecast. Depending on the area, people may choose or not to go to the sea during extreme weather phenomena. The parametric model shows that among those who get access to weather forecast, only one variable determines the use of weather forecast: it is the total income that acts negatively. 
Table 8. Determinants of the adoption of weather forecast.

\begin{tabular}{ccc}
\hline Variable & $\begin{array}{c}\text { Classic Parametric Model } \\
\text { (Full Sample) }\end{array}$ & $\begin{array}{c}\text { Parametric Model Restricted to } \\
\text { The Exposed Subsample }\end{array}$ \\
\hline Ethnicity (Serere) & $-0.669^{* * *}$ & -0.408 \\
Ethnicity (Wolof) & 0.138 & 0.142 \\
Write and read in French & $0.414^{* *}$ & 0.303 \\
Canoe owner & -0.076 & 0.067 \\
Part of fisher-folk association & 0.0032 & 0.116 \\
Training on climate change & 0.336 & 0.342 \\
Receive weather forecast via SMS & $1.074^{* * *}$ & 0.163 \\
Receive weather forecast via CLPA & $1.186^{* * *}$ & 0.416 \\
Total income & $-2.822 \times 10^{-9}$ & $-6.124 \times 10^{-9} * *$ \\
Age & $0.009^{*}$ & 0.0139 \\
Never been in school & 0.229 & 0.123 \\
Feel that the climate has changed & -0.084 & -0.432 \\
Small Coast & $0.747^{* * *}$ & 0.321 \\
Cons Coast & 0.075 & -0.076 \\
$\mathbf{N}$ & -0.804 & 0.545 \\
\hline
\end{tabular}

${ }^{* * *}=$ Significant at $1 \%,{ }^{* *}=$ significant at $5 \%,{ }^{*}=$ significant at $10 \%$. CLPA, Local Artisanal Fishing Committee.

\section{Discussion}

\subsection{Awareness and Perception of Climate Change and Variability by Fishing Communities}

Results on fisher-folks' perception of climate change showed that change in wind direction, sea level rise, reduced quantity and quality of fish and coastal erosion are the main observed changes. This finding confirms results from vulnerability studies conducted in the coastal zones of Senegal $[6,13,26,27]$. During the last fifty years, there has been an average coastal encroachment of 1 to $1.30 \mathrm{~m} /$ year, causing the destruction of human habitats and infrastructures, particularly in the Cape Verde peninsula, the Great Coast and the Small Coast. This also resulted in the increased salinization of soils, groundwater and surface waters in coastal zones in West Africa including Senegal [28]. In addition, a study carried out by Sambou et al. [17] on the perception of climate change in the Great Coast showed that the residents have a good knowledge of the risks linked to climate change. The majority of coastal residents perceive the change in terms of the marine intrusion, river flooding, scarcity and/or disappearance of certain fish species and coastal erosion. About $81 \%$ of respondents in this study say they have been affected or have a close family member affected by coastal erosion. A similar study conducted in India found that the wind direction is the most important parameter that has affected fishing in the last two decades and sea level rise was ranked as the most problematic to fisher-folks [15]. In Zambia, a study showed that the majority of fishers are aware of climate variability and experiences a decline in fish catches. These facts were overseen by the Intergovernmental Panel on Climate Change (IPCC) report $[6,29,30]$ on the impacts of climate change in coastal areas, which concluded that in the coming years, climate change will increase the challenges from existing stresses such as overexploitation of resources, loss of biodiversity and coastal erosion.

Moreover, it was noted that comparatively to the other coasts, many people from the Great Coast have perceived the effects of climate change. This could be explained by the fact that the Great Coast is subjected to significant disturbances linked to both climate change and human activities. In 2003, in the bid to reduce the repetitive flooding in the biggest city (Saint Louis) within the Great Coast, the government of Senegal dug a wide breach of $4 \mathrm{~m}$ to facilitate the flow of the water. Unfortunately, this breach has quickly enlarged to reach $5200 \mathrm{~m}$ wide in 2015, causing destruction and relocation of many villages. Studies have shown that the rapid coastal erosion in the Great Coast is linked to the creation of the breach and to the extraction of sand from the beach for building houses [31,32]. 
The management of the breach is therefore necessary to reduce the effects of climate change in the Great Coast.

Results from chi square analysis showed that fisher-folks are more and more aware of the high risk caused by the extreme weather events. Most of them have taken the decision to adopt adaptation strategies, such as the use of weather forecast, as indicated by Ouedraogo et al. [33] and Mbaye et al. [34]. Also, the use of life jacket regardless of the nature of the weather is becoming a reality in the different areas except in the Southern Coast, where almost half of the respondents did not consider the use of life jacket as necessary security measure. Indeed, life jackets are routinely recommended as a risk prevention strategy [35]. The low use of life jacket in the Southern Coast can be explained by the fact that this area is less exposed to the effects of extreme weather events given its geographical location. In addition, other factors such as religious considerations and traditional beliefs can be considered as a barrier to the use of life jacket since in this area these beliefs are strongly established. It is important to continue building the capacity of the fisher-folks to face the adverse effects of climate change though effective use of weather information and life jackets.

\subsection{The Use of Weather Forecast}

The study showed that almost $53 \%$ of respondents take appropriate decisions after receipt of the weather forecast. That is to say that when an extreme event is forecasted, at least $53 \%$ of the respondents postpone their journey to the sea. According to a study by Ouedraogo et al. [33], in Senegal, fisher-folks rely on the weather forecast to decide whether or not to go for fishing. Omar et al. [36] argued that in Malaysia, the fishing communities are a population at risk and the weather forecasts have already become part of their life. Results also demonstrated that if all the fisher-folks had the opportunity to get access to weather forecast, at least $83 \%$ of fishers would take appropriate decisions and save their lives. Indeed, better weather reporting can significantly reduce the number of fatalities arising from fishing activities, as it provides early warnings for the fisher-folks. The weather forecast can help to strengthen the adaptation of fisheries communities to the unpredictable climate [12]. The weather forecasting has contributed to reduce fishing-related costs such as fuel, ice and labor (crewmembers). Weather information makes fishing safer whilst assisting other groups of coastal communities to make early preparations against any threats from the changing climate. It also helps the fisher-folks reduce the risk exposure, hence, saving the lives of many fishers. The findings revealed that there is still a large portion of fisher-folks ( $47 \%$ ) who do not appropriately use the weather forecasts. Awareness raising activities should be organized to explain the dangers associated with being at sea during extreme weather events. In addition, some other measures such as the fishing insurance could be initiated to compensate the income loss due to the occurrence of extreme events.

Furthermore, the study revealed that the ability to write and read in French, the fishing zones (Small Coast), the access to weather forecasts through SMS and being a member of a CLPA highly influence the use of the weather forecast. In fact, the weather forecast is communicated in majority through radios and/or SMS and the latter is written in French language. Those who cannot read in this language cannot understand the content unless they have a family member who can help read the message. Most of the extreme weather events occur in the Small Coast [37], in particular, in Mbour region. Therefore, fishers in this zone tend to adopt the use of weather forecasts to reduce the risks. The damage caused by these phenomena in these areas must be widely communicated to other areas to raise the awareness and stimulate action among fisher-folks in other areas.

Findings demonstrated also that fisher-folks are more confident if they receive the information from their mobile phone (SMS) or from the CLPA [37,38]. Several authors confirmed the usefulness of information and communication technologies (ICT) in building the safety net of the fishing communities in general. Kularatne [39] argued that ICT is an essential tool for boosting the uptake of any innovation. ICT tools such as mobile phone, television, radio and GPS can bring significant reduction in the level of poverty of different communities, including the fisher-folks. Kenny [40] has found that fisher-folks use mobile phone in India to communicate with other fellows and meteorological department by 
short message services (SMS) and obtain information about weather forecast. In Lake Victoria, Africa, fisher-folks use SMS as a cheap way to get information about weather before going to sea. In addition, Omar and Chhachhar [41] and FAO [42] discovered that mobile phone is a preferred ICT tool in coastal fishing communities. However, the CLPA, as the main fisher-folks community organization, remains an excellent dissemination channel. A CLPA is a trusted entity created by a group of fishers; therefore, any advice and decision coming from this entity is well taken into consideration by its members. Also, the age was identified as slightly influencing the use of weather forecast. Young people are more reluctant in adopting the weather forecast. Young fisher-folks should therefore be targeted during awareness raising events.

\section{Conclusions}

The fisheries sector in Senegal faces many problems related to climate change. Many initiatives have been taken by authorities and partners to strengthen the resilience of communities. The objective of the study was to determine the perceptions of users on climate change and variability and their attitude toward weather forecast. The results showed that the fishing communities in Senegal are well aware of and are willing to act to adapt to the effects of climate change. These effects have been reported and largely aligned with the consequences of climate change as generally presented by scientists. Furthermore, it has been demonstrated that the access to weather forecast should be improved. Indeed, if all the fisher-folks could get access to the weather forecasts, at least $83 \%$ of them would take decision to postpone the activity of sea fishing, and this could reduce the human and material damage observed during extreme weather phenomena. To those ends, we recommend to strengthen the existing early warning systems and to sustain the weather forecast delivery system. We also recommend to continue building the capacity of the various of stakeholders in the fishing sector to stimulate greater awareness, especially for the older fisher-folks. Weather forecasts should be translated into local languages to reach large audience of the fishing communities. It is highly recommended to move from a project-subsidized approach to accessing and using weather forecasts, to a market-based private sector-led service delivery. This is why one of the potential ways of sustaining the delivery and effective use of weather and climate information services for the safety of the fishing sector is the promotion of public-private partnerships. The public sector will produce the information and the private sector will be in charge of the translation and dissemination. In addition, to minimize the risk of fatalities and loss of equipment during extreme weather events, the insurance companies might develop some insurance schemes suitable for the sector. This will allow fisher-folks to have an insurance for their equipment and get a compensation during extreme weather events. To this end, the government should create enabling environment for both the companies and clients.

Author Contributions: N.S.D. and M.N. designed, performed the data collection and analyzed them. N.S.D. and I.O. write the original draft preparation. All the authors reviewed and edited the final version of the paper. R.B.Z. writing-review and editing. All authors have read and agreed to the published version of the manuscript.

Funding: This research received no external funding.

Acknowledgments: The authors acknowledge the USAID funding support to the CINSERE project in Senegal and we are thankful to the IPAR for data collection and the community (fisher-folks and key informants) for their collaboration. USAID/CINSERE project is implemented through ICRISAT by the CGIAR Research Program on Climate Change, Agriculture and Food Security (CCAFS), a strategic partnership of CGIAR and Future Earth, led by the International Center for Tropical Agriculture (CIAT) and carried out with support from CGIAR Fund Donors and through bilateral funding agreements (For details please visit https://ccafs.cgiar.org/donors). We would like to express our deepest gratitude to the technicians of ANACIM who carried out the trainings on the ground.

Conflicts of Interest: The authors declare no conflict of interest.

\section{References}

1. Adger, W.N.; Huq, S.; Brown, K.; Conway, D.; Hulme, M. Adaptation to climate change in the developing world. Prog. Dev. Stud. 2003, 3, 179-195. [CrossRef] 
2. Ninawe, A.S.; Indulkar, S.T.; Amin, A. Impact of climate change on fisheries. In Biotechnology for Sustainable Agriculture; Elsevier BV: Amsterdam, The Netherlands, 2018; pp. 257-280.

3. Brander, K.M. Global fish production and climate change. Proc. Natl. Acad. Sci. USA 2007, 104, 19709-19714. [CrossRef]

4. Zougmoré, R.; Partey, S.; Ouédraogo, M.; Omitoyin, B.; Thomas, T.; Ayantunde, A.; Ericksen, P.; Said, M.; Jalloh, A. Toward climate-smart agriculture in West Africa: A review of climate change impacts, adaptation strategies and policy developments for the livestock, fishery and crop production sectors. Agric. Food Secur. 2016, 5, 26. [CrossRef]

5. Lam, V.; Cheung, W.; Swartz, W.; Sumaila, U. Climate change impacts on fisheries in West Africa: Implications for economic, food and nutritional security. Afr. J. Mar. Sci. 2012, 34, 103-117. [CrossRef]

6. IPCC. Climate Change 2014: Impacts, Adaptation, and Vulnerability. Part. B: Regional Aspects. Contribution of Working Group II to the Fifth Assessment Report of the Intergovernmental Panel on Climate Change; Barros, V.R., Field, C.B., Dokken, D.J., Mastrandrea, M.D., Mach, K.J., Bilir, T.E., Chatterjee, M., Ebi, K.L., Estrada, Y.O., Genova, R.C., et al., Eds.; Cambridge University Press: New York, NY, USA, 2014.

7. ANSD. Situation Économique et Sociale du Sénégal en 2015; Agence Nationale de la Statistique et de la Démographie (ANSD): Dakar, Senegal, 2018; p. 11.

8. Broutin, C. Aperçu de la Filière Halieutique au Sénégal. Working Paper; Groupe de Recherche et D'échanges technologiques (GRET): Dakar, Senegal, 2000.

9. FAO. WFC (Big Numbers Project-BNP). Fishery production system report 2008. Senegal Artisanal fisheries sub-sector. BNP reports. In Fisheries and Resources Monitoring System (FIRMS); FAO: Rome, Italy, 2009; Available online: http://firms.fao.org/firms/fishery/473/en (accessed on 21 September 2020).

10. Aggarwal, P.K.; Jarvis, A.; Campbell, B.M.; Zougmoré, R.B.; Khatri-Chhetri, A.; Vermeulen, S.J.; Loboguerrero, A.M.; Sebastian, L.S.; Kinyangi, J.; Bonilla-Findji, O.; et al. The climate-smart village approach: Framework of an integrative strategy for scaling up adaptation options in agriculture. Ecol. Soc. 2018, 23. [CrossRef]

11. Sall, M.; Samb, A.; Tall, S.M.; Tandian, A. Changements Climatiques, Stratégies D'adaptation et Mobilités. Evidence à Partir de Quatre Sites au Sénégal. Human Settlements Working Paper No.33-Rural-Urban. Interactions and Livelihood Strategies; International Institute for Environment and Development: London, UK, 2011; p. 49.

12. Shaffril, H.A.M.; Abu Samah, B.; D'Silva, J.L. The process of social adaptation towards climate change among Malaysian fishermen. Int. J. Clim. Chang. Strat. Manag. 2013, 5, 38-53. [CrossRef]

13. Niang-Diop, I.; Dansokho, M.; Faye, S.; Gueye, K.; Ndiaye, P. Impacts of climate change on the Senegalese coastal zones: Examples of the Cap Vert peninsula and Saloum estuary. Glob. Planet. Chang. 2010, 72, 294-301. [CrossRef]

14. Hasan, Z.; Nursey-Bray, M. Artisan fishers' perception of climate change and disasters in coastal Bangladesh. J. Environ. Plan. Manag. 2017, 61, 1204-1223. [CrossRef]

15. Menon, M.; Ghosh, S.; Kumar, M.S.; Rao, M.V.H.; Mahesh, V.U.; Zacharia, P.U. Fishermen's perception of climate change-A study from Andhra Pradesh. Indian J. Fish. 2016, 63, 110-119. [CrossRef]

16. Mulyasari, I.G.; Waluyati, L.R.; Suryantini, A. Perceptions and local adaptation strategies to climate change of marine capture fishermen in Bengkulu Province, Indonesia. IOP Conf. Ser. Earth Environ. Sci. 2018, 200, 012037. [CrossRef]

17. Sambou, D.; Aidara, C.A.L.; Diallo, M.A.; Mbaye, M.L. Résilience Socio-écologique des Communautés Vulnérables du delta du Fleuve Sénégal Face au Changement Climatique; Papiers Fond; Fondation Croix-Rouge française: Paris, France, 2020; Volume 23.

18. Dennis, K.C.; Niang-Diop, I.; Nicholls, R.J. Sea-level rise and Senegal: Potential impacts and consequences. J. Coast. Res. 1995, 243-261.

19. Singhal, R.; Rana, R. Chi-square test and its application in hypothesis testing. J. Pract. Cardiovasc. Sci. 2015, 1, 69. [CrossRef]

20. Rao, C.R. Karl Pearson chi-square test the dawn of statistical inference. In Goodness-Of-Fit Tests and Model Validity. Statistics for Industry and Technology; Huber-Carol, C., Balakrishnan, N., Nikulin, M.S., Mesbah, M., Eds.; Birkhäuser: Boston, MA, USA, 2002. [CrossRef]

21. Diagne, A.; Demont, M. Taking a new look at empirical models of adoption: Average treatment effect estimation of adoption rates and their determinants. Agric. Econ. 2007, 37, 201-210. [CrossRef] 
22. Wooldridge. Econometric Analysis of Cross Section and Panel Data the MIT Press; MIT Press: Cambridge, MA, USA; London, UK, 2002.

23. Dibba, L. Estimates of NERICA Adoption Rates and Impact on Productivity and Poverty of the Small-scale Rice Farmers in the Gambia. Master's Thesis, Department of Agricultural Economics, Agri-Business and Extension in Partial Fulfillment of the Requirements for the Degree of Master of Philosophy in Agricultural Economics, Kwame Nkrumah University of Science and Technology (KNUST), Kumasi, Ghana, 2010.

24. Diagne, A.; Glover, S.; Groom, B.; Phillips, J. Africa's Green Revolution? The Determinants of the Adoption of NERICAs in West Africa; SOAS Department of Economics Paper Series; Working Papers 174; University of London: London, UK, 2012. [CrossRef]

25. Hausman, J.A.; Wise, D.A. A Conditional probit model for qualitative choice: Discrete decisions recognizing interdependence and heterogeneous preferences. Econometrica 1978, 46, 403. [CrossRef]

26. Niang, I.; Ruppel, O.C.; Abdrabo, M.A.; Essel, A.; Lennard, C.; Padgham, J.; Urquhart, P. Impacts, adaptation, and vulnerability. Part B: Regional aspects. Contribution of working group II to the fifth assessment report of the intergovernmental panel on climate change. In Climate Change; Cambridge University Press: Cambridge, UK; New York, NY, USA, 2014; pp. 1199-1265.

27. Sagna, P.; Ndiaye, O.; Diop, C.; Niang, A.D.; Sambou, P.C. Les variations récentes du climat constatées au Sénégal sont-elles en phase avec les descriptions données par les scénarios du GIEC? Pollut. Atmos. 2016, 227. [CrossRef]

28. Niasse, M.; Afouda, A.; Amani, A. (Eds.) Reducing West. Africa's Vulnerability to Climate Impacts on Water Resources, Wetlands and Desertification: Elements for a Regional Strategy for Preparedness and Adaptation; IUCN: Gland, Switzerland; Cambridge, UK, 2004; Volume 17, p. 66.

29. Arthurton, R.; Korateng, K.; Forbes, T.; Snoussi, M.; Kitheka, J.; Robinson, J.; Shah, N.; Taljaard, S.; Monteiro, P. Chapter 5: Coastal and marine environments. In Africa Environment Outlook: Our Environment, Our Wealth; United Nations Environment Programme (UNEP) and African Ministerial Conference on the Environment: Nairobi, Kenya, 2006; pp. 155-195.

30. Diop, S.; Arthurton, R.; Scheren, P.; Kitheka, J.; Koranteng, K.; Payet, R. The Coastal and Marine Environment of Western and Eastern Africa. In Treatise on Estuarine and Coastal Science; Elsevier BV: Amsterdam, The Netherlands, 2011; Volume 11, pp. 315-335.

31. Diakhaté, M. Dynamique naturelle et processus de modélisation de la brèche ouverte sur la langue de Barbarie à Saint-Louis: Problématique et préalables méthodologiques. In Revue de Géographie du Laboratoire Leïde; Universite Gaston Berger: Saint-Louis, Senegal, 2012; ISSN 0851-2515(10).

32. Durand, P.; Anselme, B.; Thomas, Y.-F. L'impact de l'ouverture de la brèche dans la langue de Barbarie à Saint-Louis du Sénégal en 2003: Un changement de nature de l'aléa inondation? Cybergeo 2010, 23017. [CrossRef]

33. Ouedraogo, I.; Diouf, N.; Ouedraogo, M.; Ndiaye, O.; Zougmoré, R. Closing the gap between climate information producers and users: Assessment of needs and uptake in Senegal. Climate 2018, 6, 13. [CrossRef]

34. Mbaye, A.; Cormier-Saleme, M.-C.; Schmidt, J.O.; Brehmer, P. Senegalese artisanal fishers in the apprehension of changes of the marine environment: An universal knowledge? SSRN Electron. J. 2020. [CrossRef]

35. Peden, A.E.; Demant, D.; Hagger, M.S.; Hamilton, K. Personal, social, and environmental factors associated with lifejacket wear in adults and children: A systematic literature review. PLoS ONE 2018, 13, e0196421. [CrossRef]

36. Omar, Z.S.; Shaffril, A.M.H.; Kamaruddin, N.; Bolong, J.; D’Silva, L.J. Weather forecasting as an early warning system: Pattern of weather forecast usage among coastal communities in Malaysia. Life Sci. J. 2013, 10, 540-549.

37. Niang, N.A. Dynamique Socio-Environnementale et Développement Local des Régions Côtières du Sénégal: L'exemple de la Pêche Artisanale; Université de Rouen: Mont-Saint-Aignan, France, 2009.

38. Howell, P. Indigenous Early Warning Indicators of Cyclones: Potential Application in Coastal Bangladesh, Disaster Studies Working Paper 6; Benfield Hazard Research Centre: London, UK, 2003.

39. Kularatne, E.D. Information needs and information provision in developing countries. Inf. Dev. 1997, 13, 117-121. [CrossRef]

40. Kenny, C. ICT: Promises, opportunities and dangers for the rural future. In Proceedings of the Rural Futures Conference, Plymouth, UK, 2-4 April 2008. 
41. Omar, S.Z.; Chhachhar, A. A review on the roles of ICT tools towards the development of fishermen. J. Basic Appl. Sci. Res. 2012, 2, 9905-9911. Available online: http://www.researchgate.net/profile/Abdul_Razaque_ Chhachhar3/publication/233741219_A_Review_on_the_Roles_of_ICT_Tools_towards_the_Development_of_ Fishermen/links/54269ef50cf238c6ea7901b9.pdf (accessed on 24 January 2020).

42. FAO. Information and Communication Ttechnologies Benefits Fishing Communities. Policy Brief. New Directions in Fisheries No. 9; Food and Agriculture Organisation of the United Nations: Roma, Italy, 2007.

Publisher's Note: MDPI stays neutral with regard to jurisdictional claims in published maps and institutional affiliations.

(C) 2020 by the authors. Licensee MDPI, Basel, Switzerland. This article is an open access article distributed under the terms and conditions of the Creative Commons Attribution (CC BY) license (http://creativecommons.org/licenses/by/4.0/). 